\title{
A TEXTUAL AND CONTEXTUAL ANALYSIS OF THE HEBREW GOSPELS TRANSLATED FROM CATALAN
}

\author{
Pere Casanellas and Harvey J. Hames*
}

\begin{abstract}
The first extant translation of the four Gospels into Hebrew is to be found in a late fifteenth-century manuscript kept in the Vatican Library (Vat. ebr. 100). The study of this manuscript has to date been rather haphazard and very little has been written about it. Delcor argued in 1981 that it was probably translated from Catalan and suggested that the translator was a Jew, probably writing at the end of the fifteenth-century or the start of the sixteenth-century. In this article we attempt to demonstrate that the manuscript is a copy of the original fourteenth or fifteenth century translation. It was indeed based on a Catalan translation of the Gospels, specifically, the so-called "Bíblia del segle XIV," which is to be published in the Corpus Biblicum Catalanicum. There are small but significant hints that the translator was a Jew writing for a Jewish audience, in order to provide them with knowledge of these core Christian texts (possibly to help them to undermine Christian polemicists). However, the possibility also exists that this translation was carried out by a converso for others who, in the aftermath of 1391 and the Tortosa disputation, had converted or were considering conversion, in order to inform them about their new faith.
\end{abstract}

\section{The manuscript of the Vatican Library Vat. ebr. 100}

The first complete translation of the four Gospels into Hebrew is to be found in a late fifteenth-century manuscript written in a Byzantine hand, now in the Vatican Library (Vat. ebr. 100). This manuscript is a copy of the original translation though, sadly, there is nothing in the manuscript by means of which we can identify the copyist or the translator. Earlier translations of Matthew into Hebrew and other verses from the Gospels scattered in Jewish anti-Christian polemical works were translated from the Latin, generally from the Vulgate. However, in this case, the translator chose to make the translation based on a vernacular translation of the Gospels into Catalan.

The study of this manuscript has been rather haphazard. In 1936, Josep Maria Millàs i Vallicrosa published a short article in which he looked at Hebrew manuscripts in the Vatican library that were translated from Catalan. At the start of the article, he stated that it is by no means a full list of the possible manuscripts that might have been translated from Catalan into Hebrew. His article was written before Cassutto's catalogue of 115 of the Hebrew manuscripts in the Vatican Library appeared in $1956,{ }^{1}$ and he used the very old

\footnotetext{
* Harvey J. Hames: Department of History and Director of the Center for the Study of Conversion and InterReligious Encounters, Ben-Gurion University of the Negev. Email: hames@bgu.ac.il

Pere Casanellas: Director of the Corpus Biblicum Catalanicum, Associació Bíblica de Catalunya, and president of the Societat Catalana d'Estudis Hebraics, Institut d'Estudis Catalans, Barcelona, Catalonia, Spain. Email: pere.casanellas@b-j.cat.

This research was supported by the I-CORE Program of the Planning and Budgeting Committee and The Israel Science Foundation (596/12).

1 Biblioteca Apostolica Vaticana, Codices Vaticani Hebraici: Codices 1-115, ed. Umberto Cassuto, Bybliothecae Apostolicae Vaticanae codices manu scripti recensiti (Vatican City: Biblioteca Apostolica Vaticana, 1956).
} 
Catalogue of Stefano Evodio Assemani and Giuseppe Simone Assemani, which appeared in Rome in $1756 .{ }^{2}$ His short study does not mention the manuscript containing the Hebrew translation of the four Gospels and it is impossible to ascertain whether he saw it. ${ }^{3}$

Cassuto described the manuscript in his Catalogue noting that it could be a translation from Catalan without adding any explanations. ${ }^{4}$ Beyond this, very little has been written about this manuscript aside from commenting on its existence. A two page discussion by $\mathrm{D}$. V. Proverbio in a Vatican publication suggests that the manuscript itself was compiled in Crete but is inconclusive about the possibility of its Catalan origins. ${ }^{5}$ The catalogue of the Institute of Microfilmed Hebrew Manuscripts in the National Library in Jerusalem describes the manuscript as being from the fifteenth century in a Byzantine hand and adds Cassuto's comment about the possibility of it being a translation from Catalan. The same information appears in the new catalogue of the Hebrew Manuscripts in the Vatican Library compiled by the staff of the Institute of Microfilmed Hebrew Manuscripts. ${ }^{6}$ According to this catalogue, the translation is different from the specimens of four other translations collected by A. Marx in "The Polemical Manuscripts in the Library of the Jewish Theological Seminary of America." It refers also to the brief aforementioned text by D.V. Proverbio.

However, in 1981, Maties Delcor carefully examined chapter 10 of Matthew in the Vatican manuscript and based on grammatical formulations and the orthography of the proper names of the Apostles concluded that it was translated from Catalan. He also suggested that corrections in the margin indicate that the manuscript was read and corrected by an Italian, and he was of the opinion that it was a Jew, probably at the end of the fifteenth century or the start of the sixteenth century, who was the translator. Delcor's comments are interesting but inconclusive, and he admitted that both Provençal and Castilian were also possible sources for the Hebrew translation. He also added that even if the translation was from Catalan, it was difficult to know what version of the Gospels was used. ${ }^{8}$

The manuscript itself is a compendium containing three works. The first and largest is the translation of the four gospels, written in a different hand from the last two parts, with which there is no evident connection. It seems likely that this manuscript is a compendium compiled in Crete in the late fifteenth century for a Jewish erudite, perhaps someone like Elia Capsali (ca. 1485-1550), a Rabbi who also composed histories of Venice and

2 Stefano Evodio Assemani and Giuseppe Simone Assemani, Bibliothecae Apostolicae Vaticanae codicum manuscriptorum catalogus in tres partes distributus: in quarum prima orientales in altera Graeci in tertia Latini Italici aliorumque Europaeorum idiomatum codices, 3 vols. (Rome, 1756; rpt. Paris, 1926), 1, part. 1:1-408.

3 See J. M. Millàs i Vallicrosa, "Manuscrits Hebraics d'Origen Català a la Biblioteca Vaticana," in Homenatge a Antoni Rubió i Lluch: Miscel-lània d’Estudis Literaris Històrics i Lingüístics (Barcelona, 1936), vol. 1, 97-109.

4 Biblioteca Apostolica Vaticana, Codices Vaticani Hebraici, 144-145.

5 Delio Vania Proverbio, "Vangeli. Ebraico," in I Vangeli dei Popoli. La Parola e l'immagine del Cristo nelle culture e nella storia, eds. F. D'Aiuto, G. Morello, and A.M. Piazonni (Vatican City: Biblioteca Apostolica Vaticana, 2000), 372374 .

${ }^{6}$ Hebrew Manuscripts in the Vatican Library: Catalogue, compiled by the staff of the Institute of Microfilmed Hebrew Manuscripts in the Jewish National and University Library, Jerusalem, edited by Benjamin Richler, palaeographical and codicological descriptions by Malachi Beit-Arié in collaboration with Nurit Pasternak, Studi e Testi, 438 (Vatican City: Biblioteca Apostolica Vaticana, 2008), 67.

7 A. Marx, "The Polemical Manuscripts in the Library of the Jewish Theological Seminary of America," in Studies in Jewish Bibliography and Related Studies in Memory of A. S. Freidus (New York, 1929), 270-273.

8 M. Delcor, "Un manuscrit hébraïque inédit des quatre évangiles conservé a la Bibliothèque Vaticane (Hebr. 100)," Anuario de Filología 7 (1981): 201-219. He compares the translation to other known translations of the Gospels, such as Shem Tob ibn Shaprut's translation of Matthew and points out, correctly, that the translation is not very good. 
Constantinople, who might have been interested in having a Hebrew translation of the Gospels. ${ }^{9}$ The manuscript later became the property of the banker and bibliophile Ulrich Fugger (1526-1584) from where it made its way into the Vatican collection in 1623.10

2. Catalan as the language of the original and the Italianization of proper names introduced by copyists

It is relatively easy to show that the translation is based on a Catalan version of the Gospels.

2.1. Proper names, especially names of persons, are in general clearly transcribed from Catalan. However, as Maties Delcor rightly suggested, a copyist has often corrected these names by means of marginal corrections. Sometimes proper names appear corrupted in the text itself or have been changed into an Italian form. Finally, names usually appear in their Italian form in the headings of chapters, which must have been added by the copyist who Italianized the translation.

The list of the Apostles in Matthew 10:1-4 (f. 14r) is a good example of this state of affairs. Most names appear in the text clearly transcribed from Catalan: שימון Simon (which appears twice in the list), פנדריב Andreu, פיקמי Jacme (appears twice in the list, but on its first occurrence, probably a result of a copyist error, it appears as זאבאדיב Zebedeu, זואן Joan, טומאש Tomàs, קאניב Cananeu, יודש Judes. In three cases it seems that there

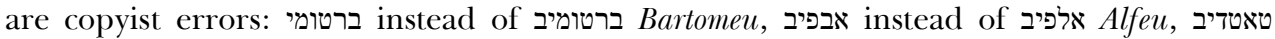
instead of טאדיב Tadeu. It has to be taken into account that the ending ייב transcription in Hebrew of the mediaeval Catalan final diphthong -eu. Some of these Hebrew forms could also be transcriptions of names written in other Romance languages, especially some Occitan dialects, but as a whole they can hardly be transcriptions from any language other than Catalan. It also has to be borne in mind that inicial $J$ - of Catalan can

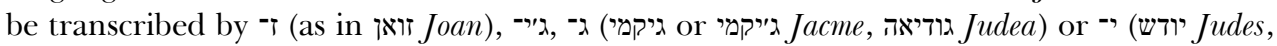
ישאוש Jesús). The transcription by "- can be explained because in medieval Catalonia, according to the testimony of Profiat Duran, the initial Hebrew letter yod was pronounced differently from the medial letter yod, probably fricative, as the letter $j$ in Catalan, instead of approximant (as the medial yod in Hebrew). ${ }^{11}$

Some of these names have been corrected by the same copyist of the text in the margins

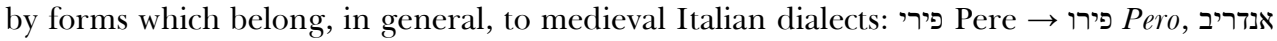

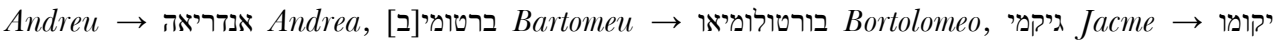
Jacomo.

In two cases we see that the Italianization of the names has been made in the text itself:

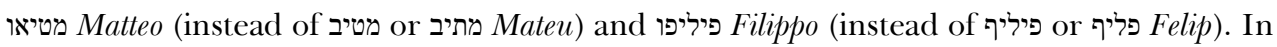

\footnotetext{
9 Proverbio, "Vangeli. Ebraico," 374.

${ }^{10}$ Much of the historical material presented here is taken from Harvey J. Hames, "Translated from Catalan: Looking at a Fifteenth Century Hebrew Version of the Gospels," in Knowledge and the Vernacular Languages in the Age of Llull and Eiximenis. ICREA Studies on Vernacularization, eds. Anna Alberni et al. (Barcelona: Publicacions de l'Abadia de Montserrat, 2012), 285-302.

${ }^{11}$ See Irene Garbell, "The Pronunciation of Hebrew in Medieval Spain,” in Homenaje a Millás-Vallicrosa, vol. 1 (Barcelona: Consejo Superior de Investigaciones Científicas, 1954), 681.
} 
both cases these names appear correctly transcribed from Catalan in many other places in the Gospels: מתיב in Mt. 9:9; Expl; Mk. 3:18; Lk. Prol:6; 6:15; פליף in Jn. 1:44,45; 11:43,46; 12:22; 14:8; פיליף Mk. 3:18; Jn. 6:5,7; 12:21,22; 14:9.

In the heading of the chapter, the evangelist's name has also been Italianized: מתיאו Matteo. The same thing happens with the name מרקו Marco in the headings of Mark (the Catalan form would be מרק Marc) and with the name לוקא Luca in the heading of Luke (the Catalan form would be ליוק Lluc). Curiously enough, in the headings of John we have the forms זואן (chapters 3 and 4) and all other chapters) which do not correspond to the transcription of the Italian form Giovani but to the Catalan form Joan.

Accordingly, the word for chapter that appears in these headings is always transcribed from Italian: קפיטולוtolo.

2.2. In some cases, the translator was not sure how to translate Catalan words into Hebrew so he just transcribed the Catalan word. Some of these transcriptions have punctuation in order to help with the pronunciation of these non-Hebrew words.

The clearest example, because of its frequency in the text, is the Catalan verb escandalitzar (Vulgate: scandalizare, English: scandalize) and the noun escàndol (Vulgate: scandalum, English: scandal). In the Vulgate there are 32 occurrences of these words. Five times (Mt. 16:23; Lk. 17:1,2; Jn. 6:62; 16:1) they have been translated in different ways, but in most of the occurrences the translator has simply transcribed the Catalan words in Hebrew characters. For instance, the text of Mt. 26:31-33 (a dialogue between Jesus and Peter just after the last supper following Jesus' announcement to his disciples that they will deny him) in the Hebrew translation compared with the text of the Vulgate:

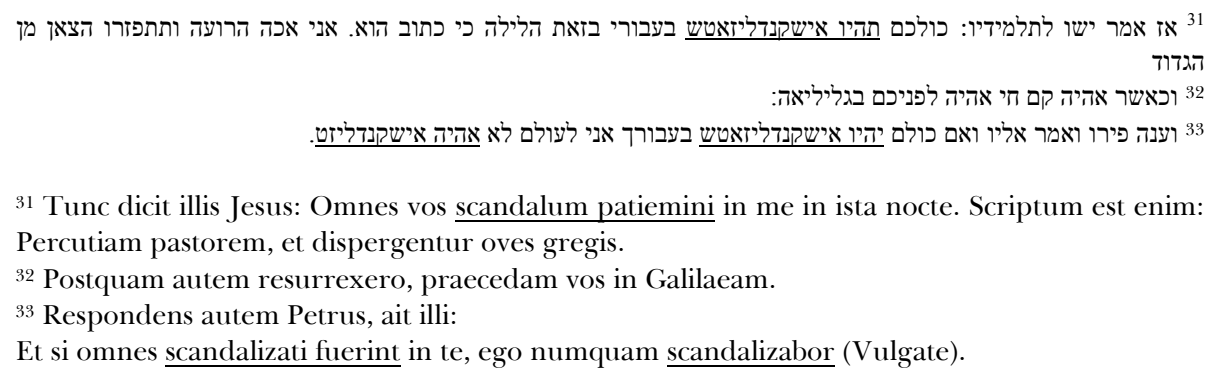

${ }^{31}$ Tunc dicit illis Jesus: Omnes vos scandalum patiemini in me in ista nocte. Scriptum est enim: Percutiam pastorem, et dispergentur oves gregis.

32 Postquam autem resurrexero, praecedam vos in Galilaeam.

${ }^{33}$ Respondens autem Petrus, ait illi:

Et si omnes scandalizati fuerint in te, ego numquam scandalizabor (Vulgate).

The Hebrew words תהיו אישקנדליזאטש are not a translation of the Latin expression scandalum patiemini "you will suffer a scandal" but correspond to the Catalan words sereu escandalitzats: the verb sereu "you will be" has been translated and the participle escandalitzats has been transcribed. The same happens in the case of יהיו אישקנדליזאטש (which corresponds to Catalan seran escandalitzats, cf. Vg. scandalizati fuerint) and אהיה אישקנדליזט (Catalan seré escandalitzat, cf. Vg. scandalizabor).

Similar forms of the Catalan verb escandalitzar transcribed in Hebrew letters, sometimes with small errors probably inserted by the copyist, appear in 20 other places; Mt. 5:29,30; 11:6; 13:41,57; 15:12; 18:6,7×3,8,9; Mk. 6:3; 9:41,42,44,46; 14:27,29; Lk. 7:23.

In Mt. 6:1, the translator seems to have had difficulty translating the Catalan word ufana "ostentation," and he first tries to translate it using the Aramaic word "crowd" and immediately afterwards he quotes the original Catalan word ufana: 
השמרו לבלתי עשות אמבוה בלעז אופנא ממעשיכם הטובים לפני העם מפני שתהיו בעיניהם אנשים טובים כי תאבדו גמול אביכם

שבשמים: השמרו ליבוים

Attendite ne justitiam vestram faciatis coram hominibus, ut videamini ab eis: alioquin mercedem non habebitis apud Patrem vestrum qui in caelis est (Vg).

Several other Catalan words are found transcribed from Catalan in the translation and are not translated in the Hebrew:

\begin{tabular}{|c|c|c|c|c|}
\hline & Latin & Hebrew & Catalan & English \\
\hline Mt. Prol: 4, 7, 11 & Evangelium & אונגילי, איונגלי & evangeli & Gospel \\
\hline Mt. Prol: 17 & evangelistae & איונגלישטש & $\begin{array}{l}\text { evangelistes } \\
\text { "evangelists" }\end{array}$ & Gospels \\
\hline Mt. 3:7 & Viperarum & [ויבריש >>] ויבדיש & vibres & vipers \\
\hline Mt. 27:28 & $\varnothing$ & סַינְדָאטט & sendat & fine silk fabric \\
\hline Mk. 4:37 & in pupi & אִינְפוּפָא & en (la) popa & in the stern \\
\hline
\end{tabular}

2.3. Other details of the Hebrew text show that it was not translated from the Latin text of the Vulgate, and very often precisely reflect the different linguistic characteristics of the Catalan original.

This can be deduced from the fact that the passive forms of the Vulgate correspond in the Hebrew translation to periphrastic forms which reflect the passive periphrastic forms of a Romance language. Three examples from the beginning of John will suffice (we enclose between parenthesis the expected Hebrew synthetic forms had the translation been based on the Latin):

\begin{tabular}{|c|c|c|c|}
\hline & Vulgate & Hebrew & Catalan \\
\hline Jn. 1:31 & manifestetur & היה מפורסם (יִגֶֶלהה) & sia manifestat/revelat \\
\hline Jn. 3:14 & Exaltari & 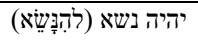 & sia exalçat \\
\hline Jn. 3:17 & Salvetur & יהיה נושע (יְְּשׁעע) & sia salvat \\
\hline
\end{tabular}

The final oclusive consonants $-b,-d$ and $-g$ of proper names are sometimes transcribed using the equivalent voiceless oclusives $\Upsilon^{-}, \Omega^{-} / v^{-}$and $\nabla^{-}$, acording to the most usual pronunciation of these consonants in Catalan (except before a voiced consonant):

\begin{tabular}{|l|l|l|l|}
\hline & Sixto-Clementine Vulgate & Hebrew & \\
\hline Mt. 1:4 & Aminadab & $-b \rightarrow ף^{-}(-p)$ \\
\hline Mt. 1:14 & Eliud & $-d \rightarrow \Omega^{-/ 0^{-}(-t)}$ \\
\hline Lk. 3:35 & Sarug & אליאוט & $-g \rightarrow \nabla^{-}(-c)$ \\
\hline
\end{tabular}


Some erroneous translations in the Gospels are easily explained when the fact that the base text was Catalan in taken into account. There are plenty of examples, but here are three taken from the first chapters of Matthew:

(a) In Mt. 4:23, the Vulgate says: "Et circuibat Jesus totam Galilaeam, docens in synagogis eorum, et praedicans Evangelium regni," that is to say: "And Jesus went about all Galilee, teaching in their synagogues, and preaching the gospel of the kingdom." However, the Hebrew translation reads: ישואש משיח היה מחפש כל ארץ גלילאה.. "Jesus Christ searched all the land of Galilee ...," which clearly does not express the right meaning of the Gospel text. The translator has clumsily translated the old Catalan verb cercava, which had the meaning "to search," as in modern Catalan, but also the meaning "to go about," "to go through," which would have been the right meaning here.

(b) In Mt. 6:10 the bad Hebrew translation ויבא למלכותך "Come to your kingdom!" instead of ויבא מלכותך "Your kingdom come!" can be explained because in fourteenthfifteenth century Catalan the vowels $e$ and $a$ in an unstressed syllable were already pronounced as shwa [ə] and are often confused in the manuscripts. The original Catalan manuscript probably had Que vingui al teu Regne "That he comes to your kingdom" (as, in fact, the Peiresc manuscript, which will be discussed in the next section, reads) instead of Que vingui el teu Regne "That your kingdom come."

(c) In Mt. 6:27 the Hebrew text says: ומי מכם יכול להוסיף לחיי גופו מדה אחת "And which one of you can add one measure to the life of his body?," which makes no sense. The Vulgate has: "Quis autem vestrum cogitans potest adjicere ad staturam suam cubitum unum." The Peiresc manuscript of the Bíblia del segle XIV has translated staturam correctly as mida, but in some manuscripts the letter $m$ was read as $u$ and the result was uida, that is to say, vida "life," the word which has been translated in Hebrew as [ם]יי[.

Curiously enough, at least in one case (Mt. 11:22) a combination of two proper names has been transcribed, including the conjunction and two prepositions, from Catalan to Hebrew instead of being translated:

\begin{tabular}{|l|l|l|l|}
\hline Latin & Hebrew & Catalan & English \\
\hline Tyro et Sidoni & dטיר אי דשידון & de Tir e [or: i] de Sidon & of Tyre and of Sidon \\
\hline
\end{tabular}

\section{The Fourteenth-Century Catalan Bible as the original of the Hebrew translation}

Among the different extant medieval Catalan versions of the Bible, there are three complete manuscripts of the Gospels:

1. The Palau Gospels or Palau Codex, dating back to the first half of the fifteenth century (Sant Cugat del Vallès, Arxiu Nacional de Catalunya, Ms. ANC1-960-T-1038 [fons Requesens-Palau]).

2. The Marmoutier manuscript, dating back to the mid-fourteenth century, which contains the whole New Testament (Paris, Bibliothèque Nationale de France, Ms. esp. 486).

3. The Peiresc manuscript, which contains the whole of the Bible and was copied between 1460 and 1470 (Paris, Bibliothèque Nationale de France, Ms. esp. 2, 3 and 4). 
The Peiresc and Marmoutier manuscripts belong to a full translation of the Bible into Catalan that was prepared during the fourteenth century and is called the FourteenthCentury Bible. However the text that appears in the Peiresc manuscript was probably copied several times between the date of the translation (the first half of the fourteenth century) and the date of the manuscript (1460-1470) and both manuscripts (Peiresc and Marmoutier) have abundant and significant differences in their translations.

A comparison of the Hebrew translation of the Gospels and these three manuscripts reveals that the Catalan translation found in the Peiresc manuscript was the basis for the Hebrew text. It should be noted, however, that the Hebrew translation often differs from the Peiresc manuscript, implying that the translation was carried out using an older manuscript than Peiresc that contained a lot of variants from the Peiresc manuscript.

In the Hebrew translation, the four Gospels appear in the classical order of the Vulgate. Before each of the Gospels, except for John, there is a short introduction, partly based on St. Jerome's introduction to his Commentary on Matthew. A comparison with the prefaces to the Gospels of Matthew, Mark and Luke in the Peiresc manuscript shows that they are the same. Most of the idiosyncrasies of the Hebrew are found in the Catalan prefaces, and aside from some minor differences the Hebrew seems to be a very literal translation of the Catalan. For instance, the introduction to Matthew states that it was written in Hebrew for the Jewish followers of Jesus, that although there were many other gospels, there are four authorized ones, and it identifies each of the four gospel authors with one of the four creatures in Ezekiel's famous vision. ${ }^{12}$ However, unlike Jerome who claims that Matthew was a Levite, it is Mark who is given that honor in both the Catalan edition and Hebrew translation. In addition, it is Matthew and not John, as in Jerome, who writes in order to defend Christianity from the heretics, and the tradition that Mark cut off one of his fingers so that he would not be able to work in the Temple as a priest, "but the Lord seeing his faith, saved what was lost, and returned his finger" is also in the Catalan preface to Mark, but is not found in Jerome. ${ }^{13}$

The Catalan prefaces to the Gospels in the Peiresc manuscript are from different sources. However, what is clear is that the translator of the Hebrew gospel used a manuscript that already contained these prefaces as it is extremely unlikely that he had different Catalan manuscripts each containing one of these prefaces. The Hebrew translation does not contain the preface to John which might suggest that the translator used a manuscript that then became the basis for the Peiresc edition of the Gospels to which additional material, such as the preface to John was then added. ${ }^{14}$ This possibility should also be considered regarding the chapter divisions of Matthew. In the Hebrew edition, there are 54 chapters, whereas in the versions later than 1230 , the chapter divisions are as found in the modern printed editions. This division into 54 chapters does not correspond to any Vulgate manuscripts pre-1230 and perhaps reflects the divisions to be found in an older Catalan manuscript of the Gospels, as the Peiresc manuscript follows the post 1230 division into chapters. In the Hebrew translation of the other three Gospels, Mark has 16 chapters as does Peiresc, Luke 25 to Peiresc' 24, and John has 21 to Peiresc' 20.

\footnotetext{
${ }^{12}$ See Thomas P. Scheck, St Jerome, Commentary on Matthew, The Fathers of the Church, vol. 117 (Washington, D.C.: Catholic University of America Press, 2008), 51-58.

13 Ms. Vatican ebr. 100, f. $47 r$.

${ }^{14}$ For more information and relevant bibliography, see Harvey J. Hames, "Translated from Catalan: Looking at a Fifteenth Century Hebrew Version of the Gospels," 291
} 
As to the text of the Gospels itself, a close comparison of the Hebrew text with the text of manuscript Peiresc and with the Vulgate shows clearly that the Hebrew translation was made from a manuscript containing the same translation copied, with many errors and variants, in the Peiresc manuscript.

Here are some examples taken from the Gospel of Matthew:

Some omissions that are found in the Hebrew translation are found also in Peiresc. In some cases this is especially notable because the omission causes the text to be grammatically incorrect, as happens with the first of the two omissions in Mt. 9.36-37. It is worth stressing that the Hebrew translation follows the order of the words in Peiresc and the modes and tenses of the verbs:

\begin{tabular}{|c|c|c|}
\hline Vulgate & Hebrew & Peiresc \\
\hline $\begin{array}{l}\text { Videns autem turbas, misertus } \\
\text { est eis: quia erant vexati, et } \\
\text { jacentes sicut oves non habentes } \\
\text { pastorem. Tunc dicit discipulis } \\
\text { suis }\end{array}$ & לתלמיזיו בלי רוער [*] העמים שהיו בצער ושוכבים & $\begin{array}{l}\text { E quant [*] les gens qui éran } \\
\text { traballades e éran [*] sens } \\
\text { pastor, hach piatat d'ells, e dix } \\
\text { alls dexebles: }\end{array}$ \\
\hline $\begin{array}{l}\text { "And seeing the multitudes, he } \\
\text { had compassion on them: } \\
\text { because they were distressed, and } \\
\text { lying like sheep that have no } \\
\text { shepherd. Then he said to his } \\
\text { disciples" }\end{array}$ & $\begin{array}{l}\text { "And when [*] the multitudes } \\
\text { which were in grief and lying } \\
{\left[{ }^{*}\right] \text { without a shepherd, he }} \\
\text { had compassion on them, and } \\
\text { said to his disciples" }\end{array}$ & $\begin{array}{l}\text { "And when [*] the multitudes } \\
\text { which were in distress and } \\
\text { were }\left[{ }^{*}\right] \text { without a shepherd, } \\
\text { he had compassion on them, } \\
\text { and said to the disciples" }\end{array}$ \\
\hline
\end{tabular}

The additions to the text of the Vulgate that we find in the Hebrew translation usually are also to be found in the Peiresc manuscript. The occurrence of the Catalan word sendat, ${ }^{15}$ already mentioned in the previous section, is one of these - in this case minor - additions (Mt. 27:28) (or a periphrastic translation of Latin coccineam):

\begin{tabular}{|c|c|c|}
\hline Vulgate & Hebrew & Peiresc \\
\hline $\begin{array}{l}\text { Et exuentes eum clamydem } \\
\text { coccineam circumdederunt ei. }\end{array}$ & אדום. & $\begin{array}{l}\text { E daspulàran-lo, e abrigàran-lo } \\
\text { da un mantell de sandat vermell. }\end{array}$ \\
\hline $\begin{array}{l}\text { "And stripping him, they put a } \\
\text { scarlet cloak about him." }\end{array}$ & $\begin{array}{l}\text { "And they stripped him and } \\
\text { covered him with a mantel } \\
\text { of red fine silk fabric." }\end{array}$ & $\begin{array}{l}\text { "And they stripped him and } \\
\text { covered him with a mantel of red } \\
\text { fine silk fabric." }\end{array}$ \\
\hline
\end{tabular}

In some cases the translation differs considerably from the Vulgate text and coincides with Peiresc, as in the second part of Mt. 4:4:

\begin{tabular}{|c|c|c|}
\hline Vulgate & Hebrew & Peiresc \\
\hline $\begin{array}{l}\text { Non in solo pane vivit homo, sed in } \\
\text { omni verbo, quod procedit de ore Dei. }\end{array}$ & $\begin{array}{r}\text { מחן השם אינינו חי על הלחם לבדו אבל } \\
\end{array}$ & $\begin{array}{l}\text { Hom no viu tan solament } \\
\text { de pa, mes de la gràcia de } \\
\text { Déu. }\end{array}$ \\
\hline $\begin{array}{l}\text { "Not in bread alone does man live, but } \\
\text { in every word that proceedeth from the } \\
\text { mouth of God." }\end{array}$ & $\begin{array}{l}\text { "Man does not live by } \\
\text { bread alone, but by the } \\
\text { grace of the LORD." }\end{array}$ & $\begin{array}{l}\text { "Man does not live by } \\
\text { bread alone, but by the } \\
\text { grace of God." }\end{array}$ \\
\hline
\end{tabular}

${ }_{15}$ On the spelling sandat instead of sendat in the quoted text of the Peiresc manuscript, see above $\S 2.3 . b$. The confusion of $e$ and $a$ in unstressed syllables is very common in this manuscript. 
The difference is only with regard to a verb in Mt. 6:17 (the Hebrew and Peiresc coincide in forms meaning "to comb" in distinction to the Vulgate, that has unge "anoint") ${ }^{16}$ :

\begin{tabular}{|l|l|l|}
\hline Vulgate & Hebrew & Peiresc \\
\hline $\begin{array}{l}\text { Tu autem, cum jejunas, unge } \\
\text { caput tuum, et faciem tuam } \\
\text { lava. }\end{array}$ & $\begin{array}{l}\text { Mas com tu dejunes, pantina } \\
\text { ton cap e lava ta cara. }\end{array}$ \\
\hline $\begin{array}{l}\text { "But you, when you fast anoint } \\
\text { your head, and wash your face." }\end{array}$ & $\begin{array}{l}\text { "But you, when you fast, comb } \\
\text { your head and wash your face." }\end{array}$ & $\begin{array}{l}\text { "But when you fast, comb } \\
\text { your head and wash your } \\
\text { face." }\end{array}$ \\
\hline
\end{tabular}

In some cases, the difference from the Vulgate stems from a copyist error in a manuscript of the Fourteenth-Century Bible. This happened, for instance, in Mt. 8:12, where the word dens (bad spelling of dents "teeth"; see two words earlier in Peiresc tramolamens instead of tremolaments) was read and copied by a copyist as deus, old Catalan form of modern Déu "God":

\begin{tabular}{|c|c|c|}
\hline Vulgate & Hebrew & $\underline{\text { Peiresc }}$ \\
\hline $\begin{array}{lll}\text { Ibi erit fletus et stridor } \\
\text { dentium. }\end{array}$ & ושם יהיה בכי ורעדה מהאל. & $\begin{array}{l}\text { Aquí serà plor e tramolamens } \\
\text { de dents. }\end{array}$ \\
\hline $\begin{array}{l}\text { "There will be weeping and } \\
\text { gnashing of teeth." }\end{array}$ & $\begin{array}{l}\text { "And there will be weeping and } \\
\text { trembling of God." }\end{array}$ & $\begin{array}{l}\text { "There will be weeping and } \\
\text { gnashing of teeth." }\end{array}$ \\
\hline
\end{tabular}

Sometimes there is a difference between the Hebrew translation and the Vulgate because the Hebrew translator has misunderstood the Catalan text of the Fourteenth-Century Bible. This is the case in Mt. 10:17, where the word parlament, which had the meaning of "assembly, council" in its context, has been understood as "speech, discourse" (a meaning that this word has in other contexts) by the translator:

\begin{tabular}{|c|c|c|}
\hline Vulgate & Hebrew & Peiresc \\
\hline $\begin{array}{l}\text { Tradent enim vos in conciliis, et } \\
\text { in synagogis suis flagellabunt } \\
\text { vos. }\end{array}$ & הבת ינהגו אתכם בדבריהם ויכו אתכם & $\begin{array}{l}\text { car ells vos amenaran en lurs } \\
\text { perllaments, e abatran-vos en } \\
\text { lurs sinagogas, }\end{array}$ \\
\hline $\begin{array}{l}\text { "For they will deliver you up in } \\
\text { councils, and they will scourge } \\
\text { you in their synagogues." }\end{array}$ & $\begin{array}{l}\text { "They will lead you by their } \\
\text { words and they will strike you } \\
\text { in their synagogues" }\end{array}$ & $\begin{array}{l}\text { "For they will lead you to their } \\
\text { councils, and they will strike } \\
\text { you in their synagogues." }\end{array}$ \\
\hline
\end{tabular}

On several occasions, the Hebrew translation makes it possible to correct errors in the Peiresc manuscript which is full of mistakes. Here is an example taken from Mt. 6:22:

16 It is interesting to consider why the Catalan has "comb" instead of "anoint." It is possible that the translator of Pieresc used a text which already had pantina ton cap, however, the act of anointing might not have made sense to the Catalan translator who instead changed the action to something more every day and common. For the Hebrew translator, combing one's hair and washing one's face when fasting might have some theological resonance, as on the two central fasts of the Jewish liturgical year, Yom Kippur (The Day of Atonement) and Tish 'a be-Av (The Ninth of Av), these two actions are forbidden. See Maimonides, Mishne Torah, Laws Regarding Fast Days, ch.5 par. 10. 


\begin{tabular}{|l|l|l|}
\hline Vulgate & Hebrew & Peiresc \\
\hline $\begin{array}{l}\text { Si oculus tuus fuerit simplex, } \\
\text { totum corpus tuum lucidum erit. }\end{array}$ & $\begin{array}{l}\text { Si lo teu vull és simpla, } \\
\text { tot lo teu cors serà dat. }\end{array}$ \\
\hline $\begin{array}{l}\text { "If your eye be simple, your } \\
\text { whole body will be full of light." }\end{array}$ & $\begin{array}{l}\text { "If your eye be simple, your whole } \\
\text { body will be bright/clear." }\end{array}$ & $\begin{array}{l}\text { "If your eye be simple, } \\
\text { your body will be given." }\end{array}$ \\
\hline
\end{tabular}

The word at the end of verse 22 in Ms. Peiresc makes no sense and does not correspond with the Latin lucidum "full of light, clear, light." In the medieval Catalan manuscripts the letters $r$ and $t$ are often very similar, and the group $c l$ - can easily be confused with a letter $d$-. It is very likely, then, that the original Fourteenth-Century Bible had clar "clear" instead of dat, and this correction should be made in the text of manuscript Peiresc based on the Hebrew.

\section{Who was the translator and who was he translating for?}

It seems reasonably clear that the historical context for the translation is a reflection of the increasingly difficult conditions faced by Jews in the Iberian peninsula in the aftermath of 1391, the Great Schism, the Tortosa disputation of the early fifteenth century and other polemics, the preaching campaigns, the civil war, and the mass conversion of many Jews including leading members of the community. As Shem Tob ben Isaac ibn Shaprut said in the introduction to his translation of the Gospel of Matthew in his monumental Even Bohan written ca. 1378:

I have seen fit to end this work I have called Touchstone with a copy / translation (leha'atik(להעתיק of the books of the gospels ... for two reasons: the one, in order to use them to respond to Christians and in particular apostates who say things about their [new] faith without really knowing anything about it, and who in this context, interpret verses from our Holy Torah in opposition to the truth and in contradiction to their [new] faith ... Secondly, to show the defects of those books and the many mistakes they contain to the venerable members of our faith, and hence, they will know and understand the advantage and stature of our faith above all the other faiths, for one does not realize the greatness and stature of a thing until he has seen its opposite. ${ }^{17}$

Shem Tob's reaction to the mass conversions is paralleled by the translator of the Gospels in a Catalan context; however, there are some interesting quirks worth pointing out:

\footnotetext{
${ }^{17}$ Libby Garshowitz, Shem Tov ben Isaac Ibn Shaprut's Even Bohan, critical edition (in preparation). This is part of Shem Tob's introductory remarks before the text of Matthew. See also George Howard, Hebrew Gospel of Matthew (Macon, Ga.: Mercer University Press, 1995), which is a revised edition of the volume he published in 1987. However, this does not include Shem Tob's polemical remarks, which are of great importance for understanding his reception of the Gospel text. Here we cite from the critical edition of Even Bohan being prepared by Libby Garshowitz which does include the polemical remarks and comments on the text. In the meantime, one can consult, Libby Garshowitz, "Shem Tov ben Isaac ben Ibn Shaprut's Even Bohan (Touchstone), chapters 2-10, based on Ms. Plutai 2.17 (Florence, Biblioteca Medicea Laurenziana) with collations from other manuscripts,” 2 vols. (Ph.D dissertation, University of Toronto, 1974).

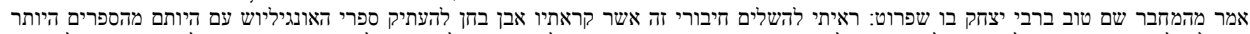

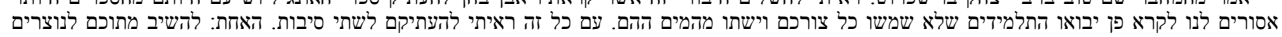

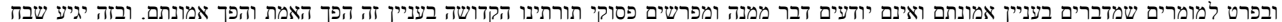

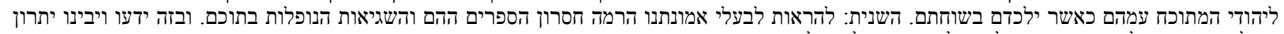

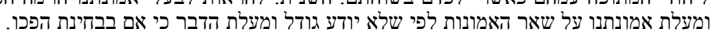


Strangely, the translator retranslates the verses taken from the Bible (Old Testament) from Catalan back into the Hebrew in a way which seems to indicate that he was not aware that he was citing the original. This is true even where the verse in the Gospels specifically mentions "as is written," in other words indicating a direct citation from the Bible.

An example of this is from Matthew where according to the Gospel Jesus cites a verse

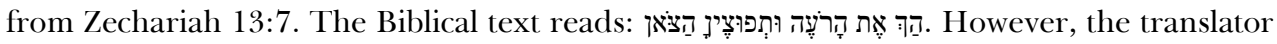
has: "אני אכה הרועה ותתפזרו הצאן" which is a direct translation from the Catalan with no reference to the original. The Biblical text does not add the first person "I will smite the pastor," but has the imperative clause "הר-smite" whereas the Catalan does have the first person "I". However, the translator does not use the biblical terminology for the rest of the citation indicating that either he did not know it, or that he purposefully chose to follow the Catalan rather than the Hebrew original. ${ }^{18}$

It is possible that the translator wished to show where the Christian text differs from the Hebrew original and by literally translating from the Catalan, he could emphasize where Christians have misunderstood or purposely misrepresented the original text so that it should affirm their Christian reading. Yet on the other hand, there does not seem to be any polemical intent in the translation and in the obvious places where one might expect it, the translation is word for word and totally neutral.

Yet, interestingly, the terminology used for crucifixion and the cross is שתי וערב (shtivaerev) as in for instance in Matthew 27 when Pontius Pilate asks what should be done with Jesus called Messiah. The Hebrew text has " והכל אמרו יהי מונח בשתי וערב" and they all said let him be placed on shti va-erev [i.e. the cross]." The Catalan has "E diguéran tots: 'Sia posat en creu!" Shti va-erev is a term adopted by the Jews in the Middle Ages to disguise the fact that they were speaking about the cross or the crucifixion and it is used broadly in antiChristian polemical works.

There are other small, but significant, hints that suggest that the translator was a Jew writing for a Jewish audience and the purpose of the literal translation was so that his contemporaries could have more knowledge of these central Christian texts. This supposition is in line with Shem Tob's introduction cited above, as well as with the intentions of the anonymous author of an almost contemporary work Hoda'at Ba 'al Din (Admission of Guilt). In the latter work, the author not only showed the internal contradictions in the Gospel texts, but demonstrated how the Gospels could be used to prove the truth of Judaism. ${ }^{19}$ Hence, this Hebrew translation could provide learned Jews with the proof texts they needed to undermine Christian polemicists. However, the possibility also exists that this translation was carried out by a converso for others who, in the aftermath of 1391 and the Tortosa disputation, had converted or were considering conversion, in order to inform them about their new faith. This translation would make sense in the context of the Tortosa disputation and in the polemical tradition of Alfonso de Valladolid who was the first convert to write polemical works against the Jews in Hebrew. ${ }^{20}$

\footnotetext{
18 Shem Tob's version in Even Bohan cites the verse exactly as it appears in the Biblical text.

19 See Harvey J. Hames, “'And on this rock I will build my community:' Jewish Use of the Gospel in FifteenthCentury Spain," in Christlicher Norden - Muslimischer Süden: Ansprüche und Wirklichkeiten von Christen, Juden und Muslimen auf der Iberischen Halbinsel im Hoch- und Spätmittelalter, eds. M. M. Tischler and A. Fidora (Münster: Aschendorff, 2011), 215-226.

${ }^{20}$ See Ryan Szpiech, Conversion and Narrative: Reading and Religious Authority in Medieval Polemic (Philadelphia: University of Pennsylvania Press, 2013), 143-173, and Harvey J. Hames, "Truly Seeking Conversion?: The Mendicants, Ramon Llull and Alfonso de Valladolid," Morgen-Glantz 20 (2010): 41-61.
} 


\section{Appendix: publication in the Corpus Biblicum Catalanicum}

The goal of the Corpus Biblicum Catalanicum (CBCat), a project of the Bible Association of Catalonia, is the publication of all extant Catalan versions of the Bible up to the nineteenth century (most of them are medieval versions) in forty-two volumes. Two volumes containing the books of Exodus, Leviticus, 1 Kingdoms and 2 Kingdoms (= 1 Samuel and 2 Samuel) of the Fourteenth-Century Bible have already been published, as well as a volume focusing on the nineteenth-century Bible. Other volumes are currently in preparation. Full information on this project can be found online at <http://cbcat.abcat. cat $/>.{ }^{21}$

The project includes some texts related to the Catalan versions of the Bible: a first volume on the history of the Vulgate (which is the origin of most of the Catalan translations) in Catalan-speaking countries, four volumes with biblical stories and two volumes on the Hebrew Bible in Catalan-speaking countries. The second of these, number 35, will contain the Hebrew Gospels translated from Catalan. The intention is to publish this volume by the end of 2015 together with an introduction in English and Catalan, a parallel translation into modern Catalan, notes, and a Glossary.

Below the transcription there will be a critical apparatus correcting errors by the copyist of the Hebrew manuscript and providing some comments on the state of the text. The notes below the Catalan translation will compare the Hebrew text with the Latin text of the Sixto-Clementine Vulgate and the Catalan text of Peiresc. The notes will also discuss special forms of the Hebrew manuscript and include comments on the different forms of proper names (transcribed from Catalan, Italianized), etc.

The Glossary will include and extensively comment on the Hebrew forms that in the opinion of the authors are worthy of notice, as can be seen in the following samples:

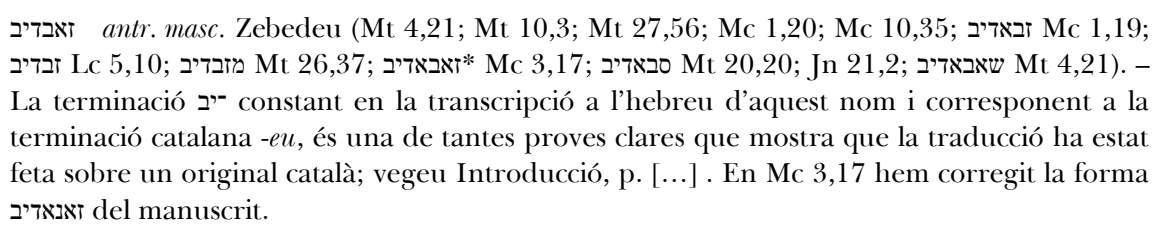

v. inf. constr. Portar (Mt 10,9; 23,4; 27,32). - Infinitiu constructe del verb נשא לישא en l'hebreu talmúdic i midràixic, corresponent a la forma לָׁ de l'hebreu bíblic i l'hebreu modern. Comentant Mt 10,9, M. Delcor, en canvi, proposa que aquesta forma hebrea transcriu el verb català lleixar en la forma de 3 a pers. del present d'indicatiu lleixa; ${ }^{18}$ cal desestimar aquesta hipòtesi perquè: $(a)$ El context sintàctic admet un infinitiu constructe però no una forma conjugada del verb. (b) El ms. Peiresc hi té precisament la forma portar. (c) El mateix mot amb el sentit ben clar de "portar," apareix també en Mt 23,4 i 27,32. Possiblement M. Delcor desconeixia l'existència d'aquesta forma poc corrent d'infinitiu constructe. [Note 18: “DELCOR, «Un manuscrit hébraïque», pp. 209 i 213.”]

\footnotetext{
21 The predecessors of the Corpus Biblicum Catalanicum, and a detailed description of the current project and its importance for Catalan philology, are given in Pere Casanellas i Bassols, "El Corpus Biblicum Catalanicum: Un antic tresor que finalment comença a ser explotat,” Llengua \& Literatura 16 (2005), 517-530.
} 


\section{BIBLIOGRAPHY}

Assemani, Stefano Evodio, and Giuseppe Simone Assemani. Bibliothecae Apostolicae Vaticanae codicum manuscriptorum catalogus in tres partes distributus: in quarum prima orientales in altera Graeci in tertia Latini Italici aliorumque Europaeorum idiomatum codice. 3 vols. Rome, 1756. Rpt. Paris, 1926.

Biblioteca Apostolica Vaticana. Codices Vaticani Hebraici: Codices 1-115. Ed. Umberto Cassuto. Bybliothecae Apostolicae Vaticanae codices manu scripti recensiti. Vatican City: Biblioteca Apostolica Vaticana, 1956.

Casanellas i Bassols, Pere. "El Corpus Biblicum Catalanicum: Un antic tresor que finalment comença a ser explotat." Llengua \& Literatura 16 (2005): 517-530.

Delcor, M. "Un manuscrit hébraïque inédit des quatre évangiles conservé a la Bibliothèque Vaticane (Hebr. 100)." Anuario de Filología 7 (1981): 201-219.

Garbell, Irene. "The Pronunciation of Hebrew in Medieval Spain.” In Homenaje a MillásVallicrosa, vol. 1, 647-696. Barcelona: Consejo Superior de Investigaciones Científicas, 1954.

Garshowitz, Libby. "Shem Tov ben Isaac ben Ibn Shaprut's Even Bohan (Touchstone), chapters 2-10, based on Ms. Plutai 2.17 (Florence, Biblioteca Medicea Laurenziana) with collations from other manuscripts." 2 vols, Ph.D dissertation, University of Toronto, 1974.

Garshowitz, Libby. Shem Tov ben Isaac Ibn Shaprut's Even Bohan, critical edition. In preparation.

Hames, Harvey J. “'And on this rock I will build my community:' Jewish Use of the Gospel in Fifteenth-Century Spain." In Christlicher Norden - Muslimischer Süden: Ansprüche und Wirklichkeiten von Christen, Juden und Muslimen auf der Iberischen Halbinsel im Hoch- und Spätmittelalter, edited by M. M. Tischler and A. Fidora, 215-226. Münster: Aschendorff, 2011.

"Translated from Catalan: Looking at a Fifteenth Century Hebrew Version of the Gospels." In Knowledge and the Vernacular Languages in the Age of Llull and Eiximenis. ICREA Studies on Vernacularization, edited by Anna Alberni, Lola Badia, Lluís Cifuentes, and Alexander Fidora, 285-302. Barcelona: Publicacions de l'Abadia de Montserrat, 2012.

"Truly Seeking Conversion?: The Mendicants, Ramon Llull and Alfonso de Valladolid." Morgen-Glantz 20 (2010): 41-61.

Hebrew Manuscripts in the Vatican Library: Catalogue, compiled by the staff of the Institute of Microfilmed Hebrew Manuscripts in the Jewish National and University Library, Jerusalem, edited by Benjamin Richler, paleographical and codicological descriptions by Malachi Beit-Arié in collaboration with Nurit Pasternak. Studi e Testi, 438. Vatican City: Biblioteca Apostolica Vaticana, 2008.

Howard, George. Hebrew Gospel of Matthew. Macon, Ga.: Mercer University Press, 1995.

Marx, A. "The Polemical Manuscripts in the Library of the Jewish Theological Seminary of America." In Studies in Jewish Bibliography and Related Studies in Memory of A. S. Freidus, 270-273. New York, 1929. 
Millàs i Vallicrosa, J.M. "Manuscrits Hebraics d'Origen Català a la Biblioteca Vaticana." In Homenatge a Antoni Rubió i Lluch: Miscel·lània d'Estudis Literaris Històrics i Lingüístics, vol. 1, 97-109. Barcelona, 1936.

Proverbio, Delio Vania. "Vangeli. Ebraico." In I Vangeli dei Popoli. La Parola e l'immagine del Cristo nelle culture e nella storia, edited by F. D'Aiuto, G. Morello, and A.M. Piazonni, 372-374. Vatican City: Biblioteca Apostolica Vaticana, 2000.

Scheck, Thomas P. St Jerome, Commentary on Matthew. The Fathers of the Church, vol. 117. Washington, D.C.: Catholic University of America Press, 2008.

Szpiech, Ryan. Conversion and Narrative: Reading and Religious Authority in Medieval Polemic. Philadelphia: University of Pennsylvania Press, 2013. 